\title{
Los viajeros románticos extranjeros y el descubrimiento del paisaje de España ${ }^{1}$
}

\author{
Nicolás ORTEGa CANTERO \\ Dpto. de Geografía.
}

Universidad Autónoma de Madrid

\section{RESUMEN}

En los relatos de los viajeros que recorrieron España durante la primera mitad del siglo XIX, se encuentran muestras elocuentes de un nuevo modo de entender el paisaje asociado al romanticismo. Aportan percepciones y vivencias interesantes del paisaje natural (marcando sus contrastes fundamentales y destacando sus notas distintivas) y del paisaje humanizado (proporcionando valiosas interpretaciones sobre el trazado tradicional y los componentes cualitativamente más apreciables de las ciudades), y con todo ello se elaboran imágenes y valoraciones con amplias resonancias geográficas. Los relatos de los viajeros románticos inician en España un modo de entender el paisaje que anuncia y anticipa en gran medida las perspectivas de la consideración moderna, desarrollada con posterioridad, de la realidad geográfica española.

Palabras clave: Romanticismo, Geografía, Viajeros, Relatos de viajes, Paisaje, Ciudad.

\section{SUMMARY}

There are, in the accounts of travellers who journeyed through Spain during the first half of the 19th century, eloquent examples of a new way of understanding landscape associated with Romanticism. They bring in interesting perceptions and experiences of the natural landscape (making note of fundamental contrasts and emphasizing distinctive features) and of the humanized landscape (providing valuable interpretations of both traditional urban layouts and the most substantial city features). All of this went into the elaboration of images and appraisals with far-reaching geographical impact. In Spain, the accounts of Romantic travellers give rise to a manner of understanding landscape that, to a large extent, both announced and were a preview of the perspectives of modern thinking on the reality of Spanish geography which would later be developed.

Key words: Romanticism, Geography, Travellers, Accounts of travels, Landscape, Town.

\footnotetext{
${ }^{1}$ Este texto se presentó en el XIX Curso de Etnología Española "Julio Caro Barojan, que se tituló La construcción nacional de la Antropología. El factor foráneo, celebrado durante el mes de marzo de 1999, bajo la coordinación de Fermín del Pino.
}

RDTP, LVII, 2 (2002): 225-244 
Dentro del amplio horizonte de las expresiones literarias que pueden interesar a la geografía, las imágenes procedentes del romanticismo resultan, por diversas razones, especialmente valiosas. Ello se debe, ante todo, a la gran atención que prestó la literatura romántica a las percepciones y vivencias de la naturaleza y del paisaje, ofreciendo puntos de vista que se acercan mucho, por sus intenciones y sus contenidos, al horizonte de la geografía moderna. Esa marcada inclinación naturalista y paisajista del romanticismo, presente en todas sus manifestaciones literarias y artísticas, aparece con suma claridad en los relatos de viajes, donde la experiencia de la naturaleza y del paisaje constituye a menudo uno de sus ingredientes fundamentales. Como ha advertido López Ontiveros (1988 y 1991), el relato romántico de viajes resulta particularmente interesante, en términos geográficos, por la expresa atención que suele dedicar al paisaje y al lugar específico, que contrasta con los planteamientos de otras narraciones viajeras precedentes, y por las perspectivas, fecundas e influyentes que aporta, respecto de la dialéctica y la búsqueda de complementariedad entre los dos polos que Pocock (1981: 339-41) denominó "early place" y "subsequent place".

Los relatos de los viajeros extranjeros que recorrieron España durante la primera mitad del siglo XIX constituyen un buen ejemplo de la caracterización y de las cualidades de ese horizonte romántico. Al tiempo que plantean numerosas consideraciones sobre los modos de vida, los tipos humanos, las costumbres y las formas de organización social, en ocasiones bastante condicionadas — como ha señalado Alberich (1987) — por ciertas ideas y creencias previas, los viajeros románticos ofrecen también continuas imágenes del paisaje que van encontrando en su recorrido. En este terreno, sus impresiones y sus juicios suelen ser más directos y originales, no están mediatizados por interpretaciones o visiones preconcebidas. A la hora de enfrentarse al paisaje de España, los viajeros románti$\cos$ no podían apoyarse en estereotipos acuñados con anterioridad. A diferencia de lo que ocurría con los aspectos históricos, sociales o políticos —que contaban con precedentes interpretativos, a menudo literarios, susceptibles de ser utilizados-, el paisaje concebido en términos modernos era una realidad nueva, modelada por los puntos de vista románticos, con nuevos valores y significados, que demandaba, para ser debidamente entendido, actitudes y perspectivas igualmente nuevas. Los viajeros llevaron así a cabo un verdadero descubrimiento del paisaje español, en el que se plasmaron con fidelidad las claves del paisajismo romántico ${ }^{2}$.

${ }^{2}$ El texto que sigue expone algunos temas que han sido tratados por el autor en diversos trabajos anteriores (véanse, en particular, Ortega Cantero 1990; 1999 y 2000). 
La corriente de viajeros extranjeros que recorre España a lo largo de la primera mitad del siglo XIX es abundante. La Guerra de la Independencia contribuyó, en un primer momento, a despertar el interés hacia lo español. Durante la guerra, algunos militares o agentes ingleses y franceses compaginaron la dedicación bélica con el ejercicio de la curiosidad viajera. Junto a las memorias de numerosos combatientes, se escriben ya algunos libros de viajes en los que asoman los renovados ingredientes de la visión romántica. Así ocurre, por ejemplo, con las Vistas de España de Locker, publicadas en 1824, en las que el autor da cuenta gráfica y literaria de los recorridos que hizo en el otoño de 1813, al tiempo que cumplía su misión de entregar a Wellington mensajes confidenciales.

Después, concluida ya la guerra, la atención hacia España se mantuvo. Con los años veinte se inició, según Alberich (1981: 33), ala Edad de Oro de la literatura viajera de tema español en lengua inglesa", que alcanzó sus momentos culminantes, casi mediado el siglo, con las obras de George Borrow (La Biblia en España, 1842) y de Richard Ford (Manual para viajeros por España y lectores en casa, 1845). Y en los años treinta y cuarenta llega a España la mayor parte de los grandes viajeros franceses, entre cuyos frutos literarios se cuentan obras tan indicativas como las Cartas de España (1831-1833) de Prosper Mérimée, Un invierno en Mallorca (1842) de George Sand, el Viaje por España (1843) de Théophile Gautier, Mis vacaciones en España (1846) de Edgar Quinet, las Impresiones de viaje (1847-1848) de Alexandre Dumas, o los Pirineos (1890) de Victor Hugo, obra póstuma donde se recogen las vivencias y evocaciones del autor durante su viaje del verano de 1843 .

Es sabido que el romanticismo concedió una importancia extraordinaria al paisaje, tanto en términos literarios y artísticos como desde el punto de vista intelectual y científico. En el paisaje vio el romanticismo la más acabada expresión —expresión fisonómica y concreta- del orden de la naturaleza y del universo, de las relaciones y correspondencias, a menudo sutiles, que vertebran el mundo. La perspectiva romántica introdujo nuevas formas de mirar y entender el paisaje, nuevos modos de percibirlo y valorarlo. Se abrían así perspectivas inéditas respecto a la manera de ver el paisaje, muy distintas de las precedentes, que conectaban con el horizonte vital y cultural, igualmente renovado, de la modernidad inaugurada por el romanticismo. Se conformaron y desenvolvieron nuevos puntos de vista, que fueron descubriendo en el paisaje nuevos valores y cualidades vitales y culturales, y todo ello traduce también la emergencia de nuevos modos de entender las relaciones del hombre con el mundo ex- 
terior. Con el romanticismo comienza el hombre a dialogar con el paisaje, y en ese diálogo se hace patente el entramado de preguntas y respuestas, de certidumbres y de dudas, de anhelos e imaginaciones que marcan el ritmo vital y cultural moderno.

El romántico es consciente de que el paisaje es una totalidad ordenada y con sentido, y para captar y comprender las relaciones que fundamentan su entidad unitaria y sus significados acude a la visión analógica y metafórica. La analogía y la metáfora permiten establecer nexos y correspondencias entre aspectos diferentes, descubrir los "hilos invisibles de la creación" de los que habló Victor Hugo (1984: 94), y, en consecuencia, hacer inteligible el paisaje como un todo ordenado, en el que es posible intuir o imaginar el sentido de las relaciones y del orden resultante. Pero el modo romántico de entender el paisaje, apoyado en la visión analógica y metafórica, no sería posible sin acudir simultáneamente a los variados recursos de la subjetividad. El pleno ejercicio de la subjetividad, que significa poner en juego todas las capacidades del sujeto, tanto las de índole racional como las de carácter sentimental e imaginativo, es imprescindible para entender correctamente la caracterización unitaria del paisaje y para adentrarse en el sentido que cabe atribuir a sus relaciones internas y al orden conjunto que de ellas resulta. Para entender lo que el paisaje es y significa, hay que adentrarse —en palabras de Humboldt (1874-5: I, X)— «en las profundidades del pensamiento, del sentimiento y de la imaginación creadoran.

Otro aspecto importante completa la perspectiva paisajista del romanticismo. Se trata de la convicción de que el hombre y el paisaje no deben entenderse como realidades separadas, sino que, por el contrario, existen nexos y continuidades entre uno y otro. El hombre forma parte del entramado de relaciones que recorren el mundo, y por tanto se dan continuas correspondencias entre lo exterior y lo interior, entre el universo y la conciencia. Como advirtió Humboldt (1874-5: II, 4), existen "analogías misteriosas y morales armonías que ligan al hombre con el mundo exterior". La visión analógica y metafórica no sólo descubre relaciones entre las distintas partes del paisaje, sino que permite también establecerlas entre el paisaje y la conciencia del hombre que lo mira. Debido a esa estrecha conexión, el paisaje se interioriza, se convierte en un estado de conciencia; y el romántico, cuando habla del paisaje, habla también de sí mismo. La experiencia paisajística del romanticismo entraña así un alto grado de compenetración entre el hombre y el paisaje. El paisaje no es algo ajeno al hombre, desconectado de sus ideas y sentimientos, sino que, por el contrario, mantiene con él lazos profundos y duraderos. Y esta compenetración con el paisaje alentada por el romanticismo es otra de las claves mayores del paisajismo moderno. 
El romanticismo ofrece una nueva visión del paisaje y de las relaciones del hombre con el paisaje que constituye el punto de partida de todas las perspectivas paisajistas de nuestra modernidad. Esa visión tiene en cuenta y aprecia los significados y el sentido del paisaje, lo que supone como totalidad ordenada, sus cualidades y dimensiones de distinta índole. Valora su interés intelectual y científico, las posibilidades que ofrece a las ideas y al pensamiento, pero también, al tiempo, valora sus componentes éticos y estéticos, aquello que concierne más directamente a la esfera del sentimiento y de la imaginación. El romanticismo propone, en suma, una acabada valoración cultural del paisaje, integradora y de gran aliento, que lo convierte en uno de los focos predilectos de atención de la cultura moderna.

El viajero Richard Ford ofrece algunos ejemplos claros de ese modo de valoración. Da cuenta, a lo largo de sus escritos, de las impresiones que le producen los paisajes españoles, y destaca también sus cualidades principales. Valora sus rasgos estéticos y no es insensible a su dimensión ética. Y también tiene en cuenta su interés intelectual y científico, las posibilidades que entrañan desde el punto de vista del conocimiento naturalista, principalmente geológico y botánico. Todos estos aspectos, merecedores de una investigación más amplia y detenida que la desarrollada hasta entonces, "ofrecen a los autores noveles deseosos de originalidad —escribe Ford (1974: 292) — asuntos más dignos que las viejas historias de bandidos, toreros y ojos negros". Además, el estudio de la caracterización geológica o botánica de los paisajes españoles tiene la ventaja de propiciar el siempre recomendable contacto directo con la naturaleza. Esas investigaciones son, según Ford (1980-3: I, 118, 171, y II, 19), "Sanas y agradables, por tratarse de actividades que se realizan al aire libre y por poner al interesado en íntimo contacto con la naturaleza". Porque, para el autor, la recompensa que se obtiene de la "íntima comunión con la naturaleza" es siempre la "salud del cuerpo y el alma". Y se lamenta, en fin, del escaso arraigo del "amor de la naturaleza" entre los españoles de entonces, y de su no menos escaso interés en investigar sus procesos". En este sentido, Ford (1974: 33) plantea una contraposición ilustrativa y no desatinada entre esa figura del español, en general sedentario y desinteresado por la naturaleza y su estudio, y la del inglés, "amante de la Naturaleza y curioso de aventuras", y mucho más inclinado hacia el conocimiento de los rasgos naturales, geológicos y botánicos, de los paisajes que recorre.

El romanticismo prestó una especial atención, desde el principio, al entendimiento de las relaciones entre el hombre y el paisaje. Aclaró la compleja envergadura de tales relaciones, que llegan hasta la esfera de lo 
espiritual, e insistió en destacar los sustanciales beneficios que puede deparar al hombre el contacto directo con el paisaje. A través de ese contacto, el hombre presiente y siente la presencia de un orden superior que le atañe directamente, descubre correspondencias entre las cualidades de ese orden y las de su propia conciencia.

La impresión que deja en nosotros el espectáculo de la Naturaleza -escribe Humboldt (1961: 113-4) — es provocada menos por la fisonomía particular del paisaje que por la luz que destaca montes y campos, ya iluminados por el azul del cielo, ora ensombrecidos por las nubes. Igualmente la pintura de escenas naturales nos impresiona más o menos vivamente, según está más o menos en armonía con las necesidades de nuestros sentimientos. Pues el mundo exterior físico se refleja, como en un espejo, en el mundo interior moral. El contorno de las montañas que coronan el horizonte en una lejanía nebulosa, el tinte sombrío de los bosques de abetos, el torrente que se precipita tumultuosamente a través de rocas abruptas, en fin, todo lo que forma el carácter de un paisaje se une, por un antiguo lazo misterioso, a la vida sentimental del hombre.

Este lazo proporciona los más nobles goces de la Naturaleza. [...] El recuerdo de un país rico, lejano, el aspecto de una vegetación libre, vigorosa, recrean y fortalecen el alma; lo mismo que el espíritu, oprimido por el presente, retrocede voluntariamente hacia la edad primitiva, y se alegra con la grandeza sencilla de la Humanidad.

Las palabras anteriores de Humboldt dejan ver un aspecto interesante del modo romántico de entender las relaciones entre el hombre y el paisaje. En la medida en que el paisaje es la expresión de un orden natural, la solidaridad del hombre con el paisaje es la vía más segura para que éste afiance o reconquiste su naturalidad, para que mantenga actitudes y comportamientos armónicamente integrados en el ámbito de la naturaleza. La relación con el paisaje adquiere así una cualidad importante: ayuda al hombre a recuperar la naturalidad, la armonía natural, en un mundo en el que muchas otras fuerzas tienden a distanciarle de ella. Frente a los artificios de la vida moderna, frente a todo lo que aparta al hombre de su ser natural, la relación con el paisaje le permite volver a encontrar la naturalidad, armonizar sus experiencias con el orden de la naturaleza. Los románticos expresan a menudo esa capacidad naturalizadora del contacto con el paisaje, la posibilidad de vencer, a través de ese contacto, los dolores, las tristezas, las pasiones, las agitaciones y las tormentas de la vida que oprimen el espíritu. La idea de armonía natural es fundamental en el entendimiento de las relaciones entre el hombre y el paisaje que ofrece el romanticismo.

Pero no es sólo en términos individuales como se manifiesta la solidaridad entre el hombre y el paisaje. El romanticismo ofrece asimismo la idea de que esa solidaridad tiene también una dimensión colectiva o so- 
cial. Los rasgos característicos y esenciales de los pueblos muestran asimismo correspondencias significativas con los paisajes en los que viven y se desenvuelven. El paisaje adquiere, de este modo, una significación histórica y, con ello, se refuerza todavía más su valor cultural. La historia de un pueblo es inseparable de su paisaje, que expresa, de forma material y simbólica, sus rasgos y tendencias principales. El paisaje se convierte así en una referencia histórica fundamental, en un signo visible de la identidad colectiva de los pueblos. El paisaje es un testimonio vivo de la propia historia, y de ahí que su conocimiento y apreciación pueda conectarse directamente - como, de hecho, se hizo a menudo- con el fomento del verdadero patriotismo. Muchas de las defensas del paisaje que se han sucedido en los dos últimos siglos han apelado a esa conexión con el patriotismo, y en ello hay que ver un modo de manifestación del modo de entender de la relación solidaria entre paisaje e historia que comienza con el romanticismo.

Junto a la delimitación de las coordenadas generales de la valoración del paisaje, el romanticismo introdujo también nuevos gustos y preferencias en ese terreno. La montaña -ignorada, menospreciada o temida con anterioridad - pasa ahora a ser el ámbito predilecto del horizonte romántico. En los lugares montañosos se halla la más acabada expresión de los rasgos naturales y paisajísticos que ese horizonte ensalza, al tiempo que en la llanura se ve la antítesis, la negación, de todos ellos. El Obermann de Senancour, verdadero manifiesto de la visión romántica de la naturaleza y el paisaje, aporta un buen y temprano ejemplo de tales valoraciones. El autor desprecia la llanura y elogia las múltiples cualidades de la montaña, donde es posible encontrar la verdadera libertad, y elevarse hasta un grado superior de compenetración con la naturaleza y el paisaje. En la montaña, dice Senancour (1930: I, 38-9, 61, 64, 82), "la Naturaleza entera expresa elocuentemente un orden superior, una armonía más visible, un conjunto eterno". Al elogio de la montaña acompaña el del bosque. El romanticismo gusta también de la vegetación densa y vigorosa. Es el ideal de la selva del Norte el que vital y estéticamente convence al romántico. Senancour declara igualmente su amor hacia "los bosques espesos", donde se manifiesta con fuerza el "poder de la naturaleza" y es posible lograr "un sentimiento de paz, de libertad, de alegría salvaje".

Los viajeros extranjeros que recorrieron España durante la primera mitad del siglo XIX incorporaron fielmente las claves y las preferencias del entendimiento romántico del paisaje. En sus relatos, se muestra con claridad la idea de que el paisaje es una entidad unitaria, la resultante de un 
conjunto de componentes relacionados entre sí, cuyo entendimiento requiere el concurso de la visión analógica y metafórica y el pleno ejercicio de la subjetividad. Y también aparece con nitidez la convicción de que existen nexos y correspondencias entre el hombre y el paisaje, de que entre ambos existen solidaridades profundas. Respecto de lo primero, los viajeros románticos ofrecen múltiples imágenes del paisaje español en las que se señala la presencia simultánea de sus diversos componentes y el resultado conjunto de sus relaciones. A propósito de los Pirineos aragoneses, por ejemplo, escribe Richard Ford (1980-3: X, 57) lo siguiente: "El paisaje es alpino, una mezcla de montañas, precipicios, glaciares y bosques, animados por cataratas o huracanes". Y, hablando del ámbito montañoso de las proximidades de Irún, en el País Vasco, advierte Théophile Gautier (1920: I, 36-7) lo que sigue:

El paisaje era encantador, quizá un poco suizo, y de muy variado aspecto. Crestones de montañas, por cuyos intersticios se divisaban otras cadenas más elevadas, se redondeaban a los lados del camino; sus laderas, abigarradas de cultivos diferentes, con bosques de robles verdes, formaban un vigoroso contraste con las cimas lejanas y esfumadas; los pueblecillos con sus tejas rojas se extendían al pie de las montañas entre macizos de árboles [...]. Torrentes, caprichosos como mujeres, van y vienen formando pequeñas cascadas, se bifurcan, vuelven a unirse, a través de rocas y guijarros, de la manera más divertida, y sirven de pretexto a multitud de puentes de lo más pintoresco del mundo. [...] Macizos de árboles y grupos de encinas realzan felizmente las grandes líneas y los tintes vaporosamente severos de las montañas.

No menos expresiva de la atención prestada por los viajeros a los componentes del paisaje y sus relaciones, a veces cambiantes, resulta la caracterización que ofrece George Borrow (1921: II, 103) del valle leonés de Bembibre:

Acaso no se encuentre, aun buscándolo por todo el mundo, un lugar cuyas ventajas naturales rivalicen con las de esta llanura o valle de Bembibre, con su barrera de ingentes montañas, con sus copudos castaños, y con los robledales y saucedas que visten las márgenes del río, tributario del Miño. Es verdad que, cuando yo pasé por allí, el luminar del cielo ardía en todo su esplendor, y las cosas, alumbradas por sus rayos, aparecían brillantes, prósperas y jocundas. No aseguro que aquellos lugares me hubieran producido igual admiración contemplados a otra luz; pero es indiscutible que siendo tantas sus cualidades no pueden por menos de producir en cualquier tiempo hondo deleite; a la belleza apacible de un paisaje inglés júntase allí un no sé qué de grande y de agreste, y tengo para mí que el hombre nacido en aquellos valles, a no ser muy insaciable y turbulento, no querrá abandonarlos jamás.

Para los viajeros románticos, el paisaje expresa el orden de la naturale- 
za, el orden resultante del conjunto de nexos y correspondencias, a menudo sutiles, que unen las diferentes partes de la naturaleza, un orden que es preciso captar y desentrañar para llegar a comprender su sentido y sus significados. En el relato de su viaje por los Pirineos, lo advierte Victor Hugo (1984: 94) con bastante nitidez: "todas las partes de la naturaleza, incluso las más dispares a primera vista, se relacionan entre sí por multitud de armonías secretas, hilos invisibles de la creación que percibe el contemplador, que hacen del gran todo una red inextricable, viviendo una sola vida, alimentado por una única savia, uno en la diversidad, y que constituyen, por decirlo así, las raíces mismas del ser.. Además, el viajero romántico es consciente de que esas relaciones y esas armonías no se detienen en el mundo exterior, sino que llegan hasta su propio mundo interior. El paisaje llega a ser así un estado de conciencia: "por la larga contemplación del bello mundo externo —escribe Ford (1974: 288)—, se sorprenden trozos del bello mundo interno". La compenetración entre el paisaje y la propia conciencia, entre el mundo exterior y el interior, que expresa uno de los rasgos más característicos del paisajismo moderno, es continua en los viajeros románticos que recorrieron España. Buena muestra de ello son las sensaciones y vivencias que experimenta Gautier (1920: 102-3) cuando atraviesa, por el alto del León, la Sierra de Guadarrama:

\begin{abstract}
Las montañas se elevaban más y más; apenas habíamos franqueado una se presentaba otra más alta, antes oculta a nuestros ojos; no bastaron las mulas y hubo que recurrir a los bueyes, lo cual nos permitió apearnos del coche y concluir de subir la sierra a pie. Yo estaba embriagado de aquel aire tan vivo y tan puro; me sentía tan ligero, tan alegre, tan lleno de entusiasmo, que daba gritos y saltos como un cabritillo; experimentaba el deseo de tirarme de cabeza en aquellos encantadores precipicios, tan azules, tan vaporosos, $\tan$ aterciopelados; hubiera querido hacerme arrollar por todas las cascadas, meter los pies en todos los manantiales, coger una hoja de cada pino, revolcarme en la nieve chispeante, mezclarme con aquella Naturaleza y fundirme como un átomo en aquella inmensidad. Bajo los rayos del Sol, las altas cimas fulgían y chispeaban deslumbradoras como las basquiñas bordadas de lentejuelas de las bailarinas; otras cumbres hallábanse entocadas de nubes y se confundían con el cielo por gradaciones insensibles, pues nada hay que se parezca tanto a una montaña como una nube. Todo eran ondulaciones, escarpaduras, tonos y formas de que no hay arte que pueda dar idea: ni el pincel ni la pluma.
\end{abstract}

También incorporan los viajeros románticos la idea de que existen relaciones estrechas y duraderas entre el paisaje y los hombres que lo habitan. Están convencidos de que los grupos humanos y los paisajes son solidarios, de que entre unos y otros se establecen lazos de unión sumamente importantes. La caracterización de los ámbitos castellanos y manchegos expresa al tiempo, según Ford (1980-3: I, 199-200), ala condición 
física" de esas tierras y "las cualidades morales" de quienes las habitan. "La ausencia general de árboles —añade Ford- expone estas amplias y descubiertas llanuras a la rabia y violencia de los elementos; casas de adobe sumamente pobres, esparcidas aquí y allí en la extensión desolada, dan un lamentable refugio a la población, pobre, orgullosa e ignoranten. Y Edgar Quinet (1931: 99) habla también de manera bastante expresiva, ante el paisaje de La Mancha, de esas mismas correspondencias:

A lo lejos, la tierra se asemeja al campesino español. Desnuda como él, se exhibe al sol en su capa agujereada de cizaña. Es silenciosa como él: ni un canto de pájaro, ni un murmullo de arroyuelos, ni de follaje. Sobria como él, sólo el rocío la fertiliza. Independiente como él, ni hoyos, ni empalizadas: la igualdad está grabada en su faz. Como el campesino no reconoce más que la soberanía de Dios, la tierra no se inclina más que a los pies de las rocas eternas de Sierra Morena.

La visión de los paisajes españoles que proporcionan los viajeros extranjeros de la primera mitad del siglo XIX se atiene también con claridad a los gustos y preferencias del horizonte romántico. De acuerdo con los cánones alpinos y nórdicos que presiden esos gustos y preferencias, los viajeros románticos muestran, a la hora de dar cuenta de los paisajes naturales españoles, una marcada predilección hacia los ámbitos montañosos y boscosos y una no menos marcada animadversión hacia los ámbitos llanos. Las mejores imágenes ofrecidas por los viajeros, en este sentido, son las que se refieren a los paisajes españoles de montaña, donde a la presencia del roquedo se añade con frecuencia la de la vegetación -como sucede, por ejemplo, en numerosos lugares de los Pirineos, donde, en palabras de Ford (1980-3: X, 83), "el paisaje es una espléndida mezcla de roca y bosque —, y a los paisajes húmedos y boscosos del Norte peninsular, a menudo conectados, de forma más o menos directa, con formas montañosas próximas.

Los ámbitos de montaña interesaron especialmente a los viajeros románticos, que desplegaron ante ellos las mejores posibilidades de sus nuevos modos de ver, sentir y pensar el paisaje. Su visión de las montañas españolas - de los Pirineos o de Sierra Morena, de la Sierra de Guadarrama o de Sierra Nevada, por ejemplo- constituye, sin duda, uno de los logros mayores y más valiosos de su perspectiva paisajística. Aplicando por vez primera los puntos de vista del paisajismo moderno, de cuño romántico, los viajeros supieron descubrir las cualidades y los valores de los parajes españoles de montaña, y las imágenes que ofrecieron de ellos constituyeron el punto de partida de todo el acercamiento posterior - cultural, naturalista y geográfico- a esos mismos ámbitos.

La gran sensibilidad de los viajeros románticos respecto de los paisa- 
jes españoles de montaña, que entendieron como la más acabada y valiosa expresión del orden y de las cualidades naturales, les llevó además a denunciar las situaciones que amenazaban su integridad. Esta visión crítica, que inició también actitudes y opiniones que habrían de prolongarse después, se manifestó con gran claridad a propósito de la deficiente conservación de los bosques españoles, sometidos con frecuencia al castigo de las talas desmedidas. "Los bosques españoles -escribe Ford (1980-3: III, 75) - se talan por todas partes de la manera más imprevisoran. En otra ocasión, el mismo Ford (1974: 33) comenta: "Los bosques también han sufrido enormemente con la negligencia, el despilfarro e imprevisión de los naturales, que arrancan más de lo que necesitan, y nunca repueblan". Y se refiere también Ford (1980-3: X, 82), en términos igualmente elocuentes, a los nefastos efectos de la explotación maderera del Pirineo aragonés: "el daño que se está haciendo a estos nobles bosques es verdaderamente escandaloso".

El bosque es para Ford (1980-3: V, 94) un elemento estéticamente importante del paisaje: "nada más bonito - escribe- que las lejanas vistas de los pueblos rodeados de bosques". Pero el bosque es, al tiempo, algo más: un indicador y hasta un símbolo del estado material y espiritual del país y de sus posibilidades futuras, en una visión que anticipa algunos de los rasgos del posterior alegato regeneracionista en favor del arbolado. Aprecia Ford (1980-3: X, 69-70) sobre todo los bosques aún no sometidos al hombre. En pleno Pirineo, contempla el bosque primigenio, bien a salvo del hacha del leñador. Los abetos, tejos, robles, hayas, abedules, fresnos, etc., se elevan, altos y delgados, en su búsqueda de aire y luz. Sus elegantes troncos contrastan con las bastas rocas, como de Salvator Rosan.

Ford, siempre atento a las agresiones al paisaje, expone además, con buen sentido geográfico, algunas de las consecuencias que la desaparición del arbolado manifiesta en relación con la humedad, la acción erosiva y el funcionamiento fluvial. La ausencia de vegetación arbórea desencadena una serie de efectos naturales que Ford (1980-3: I, 204) describe de manera elocuente:

No hay nada que frene la evaporación, nada que proteja y preserve la humedad. El suelo se va volviendo más y más seco y calcinado, y en algunas partes ha llegado incluso a ser incultivable. Otra seria amenaza, que resulta de la falta de plantaciones, es que las laderas de los montes están expuestas por todas partes a la constante erosión del suelo después de las lluvias intensas, porque no hay nada que impida la bajada del agua, y de aquí las cimas de piedra, desnudas y estériles, de muchas de las sierras, que han sido raspadas y peladas de toda su tierra capaz de producir vegetación: son esqueletos cuya vida se ha extinguido. No solamente se pierde el suelo de esta manera, sino que los detritos, empujados ladera abajo por el agua, forman barras en las bocas de los ríos, o bien rellenan y 
levantan sus lechos, exponiéndolos de esta manera a salirse de sus cauces y convirtiendo las llanuras contiguas en pantanos pestilentes. El abastecimiento de agua, producto de las lluvias periódicas, y que debiera rellenar los depósitos de los ríos, desaparece inmediatamente en inundaciones violentas y no en un desagüe suave y gradual.

La temprana inquietud proforestal de Ford no deja de recordar, en más de un aspecto, los argumentos luego utilizados por quienes se ocuparon de defender y fomentar el arbolado en España. Las carencias vegetales, sobre todo de la España interior, se relacionan con la falta de agua. En Castilla, dice Ford (1980-3: VII, 12), "el agua es muy escasa, no sólo para el riego, sino incluso para el uso doméstico, y la naturaleza y la gente son igualmente adustas y requemadas; todo es pardo: la casa, la ropa, la esposa y el asnow. Tal deficiencia es penosa porque el agua equivale a vida y fertilidad: "el agua —afirma Ford (1980-3: III, 93) — es riqueza" y su presencia "separa el desierto del paraíso; todo lo que está bajo su influencia es verde y fructífero, y todo lo que yace más allá de ella se vuelve árido y parduzcon.

Pero sería un error pensar que la penuria forestal de Castilla depende sólo de la sequía. Traduce también la deplorable y continua animadversión del castellano hacia los árboles. Charles Dembowski (1931: I, 34), viajero por España entre 1838 y 1840, dice haber comprobado que las gentes de los alrededores de Madrid "han heredado de los moros un odio vivo a los árboles, que consideran únicamente como otros tantos asilos de pájaros que viven a su costan. Ford (1980-3: I, 204, y VII, 11) habla asimismo de "la curiosa antipatía que los habitantes del interior sienten hacia los árboles". Y después añade: "Los castellanos sienten especial antipatía hacia los árboles y, como los orientales, raras veces los plantan, excepto los frutales o los que dan sombra a sus alamedas. Azorín (1920: 61-70) hablará también después, en uno de sus artículos de intención regeneracionista, de ese mismo "rencor tradicional al árbol", de ese "odio" que llega a definir toda una "tradición castiza, neta, innegable, francamente española, en lo que atañe al árboln.

A diferencia de lo que ocurre con los paisajes de montaña, los de las llanuras apenas interesaron a los viajeros románticos. Los paisajes del interior de España, los amplios ámbitos de las dos mesetas, no disponían de alicientes para el paisajismo romántico. Yendo desde Madrid hacia Toledo, Gautier (1920: I, 197) habla, por ejemplo, de uun camino detestable, en una llanura inmensa, polvorienta, cubierta de trigos y de cebadas, cuyo amarillo pálido contribuye a la monotonía del paisaje. . Ford (19803: II, 328) se refiere a las desagradables sensaciones que experimentan los viajeros al atravesar las llanuras de La Mancha, "fatigados por perspec- 
tivas de miseria inmutable y por una falta total de cualquier cosa de interés, tanto en el hombre como en sus obras, o en la naturaleza de que se ven rodeados". Y habla también Ford (1980-3: X, 87) de "las regiones desnudas de Castilla la Viejan, donde lo mejor que puede hacer el viajero es "salir de nuevo de ellas lo más rápidamente que le sea posible". Los viajeros románticos no llegaron a apreciar el paisaje castellano, que hubo de esperar algunos años, hasta el último tercio del siglo, para lograr, en el horizonte cultural inicialmente promovido por la Institución Libre de Enseñanza, el reconocimiento de sus cualidades y valores.

La nueva perspectiva paisajística de los viajeros románticos no se limitó a considerar los ámbitos de carácter predominantemente natural. También se fijó en los paisajes más humanizados, y, dentro de ellos, prestó bastante atención a los de índole urbana. En este terreno, los viajeros románticos muestran preferencias igualmente claras: apenas les interesan las aglomeraciones modernas, con sus secuelas de uniformidad y monotonía, frecuentes en sus países de origen, y se sienten fuertemente atraídos por las ciudades que todavía mantienen caracterizaciones más originales, sugerentes y pintorescas. Los viajeros románticos prefieren las ciudades españolas de más acusada personalidad, aquellas que, por variadas razones, conservan viva la impronta de su singularidad. El ámbito que, en este sentido, acaparó la mayor parte de la atención de los viajeros fue Andalucía. Junto a la habitual consideración de otros núcleos urbanos también atractivos - como Toledo, con su densa historia y su tinte legendario, o Aranjuez, con sus bellos y sugerentes jardines-, los viajeros románticos concentraron fundamentalmente sus puntos de vista sobre el paisaje urbano en las ciudades andaluzas. "Sevilla, Córdoba, Ronda y Granada —escribe Ford (1980-3: II, 17)—, cada una a su manera peculiar, no tienen rival ni en España ni en Europan.

El viajero romántico presta particular atención a ciertos rasgos y a ciertos ámbitos de las ciudades españolas. Entre los primeros se cuenta el peculiar trazado de las calles, de lejano ascendiente medieval o moro, de algunas ciudades, que se estima muy sensato y sabiamente adecuado a las condiciones térmicas existentes.

Las calles de Toledo - dice Gautier (1920: I, 201-2)— son extremadamente estrechas; podrían darse las manos de una ventana a otra, y nada más fácil que saltar de balcón a balcón, si las hermosas rejas y los encantadores barrotes de esa rica forja [...] no pusieran coto e impidieran las familiaridades aéreas. Esta poca anchura haría poner el grito en el cielo a los partidarios de la civilización, que no sueñan sino con amplias plazas, anchos jardines, calles inmensas y otros 
embellecimientos más o menos progresivos: sin embargo, nada más razonable en un clima tórrido que las calles estrechas.

Tal trazado expresa "la sabiduría de los antepasados, que no sacrificaban todo a una regularidad estúpida", y sus benéficos efectos son notorios: “En el fondo de estas estrechas cortaduras, hechas según las manzanas de casas — precisa Gautier (1920: I, 202)—, se disfruta un fresco y una sombra deliciosos; se circula a cubierto en las ramificaciones y porosidades de ese pólipo humano que se llama una ciudad; los chorros de plomo derretido que Febo-Apolo vierte desde el cielo a las horas del mediodía no os alcanzan nunca, pues los salientes de los tejados sirven de sombrilla".

Los patios de las casas - los patios andaluces, ante todo- son otro de los aspectos continuamente destacados y encomiados por los viajeros románticos. A propósito de Sevilla, escribe Borrow (1921: III, 192-3): “Las casas, construidas casi todas conforme el patrón moro, tienen en el centro un patio cuadrangular, donde una fuente de mármol surte de continuo agua cristalina. En la estación del calor, los patios se cubren con un toldo, bajo el cual pasa la familia la mayor parte del día. A menudo tales patios se encuentran adornados de arbustos, naranjos, toda clase de flores y a veces una pajarera pequeña, de suerte que no es concebible mayor delicia que la de tenderse allí a la sombra, oyendo el canto de los pájaros y el rumor de la fuenten.

En una "posada de buena apariencia", encuentra Gautier (1920: II, 134 , 41) un "patio de columnas cubierto de un soberbio tendido", perfumado por "mirtos, granados y jazmines, en tiestos de barro rojo", y con "una media luz, tamizada y llena de misterio". Evoca luego la casa granadina donde estuvo instalado, con un patio rodeado de columnas de mármol blanco, coronadas de capiteles morunos", y con "un estanquito con su surtidor" y "una gran estera de esparto, que hacía las veces de tendido". Allí, más que en el cuarto, discurre la vida de la casa: "sin el patio —añade- [...] las casas de Andalucía no serían habitables". La seducción del patio, con su vela y su séquito de rumores, luces y perfumes, no escapa a la percepción de Gautier (1920: II, 14):

El patio es una invención encantadora; en él se disfruta de frescura y de más espacio que en el cuarto; se puede pasear, leer, estar solo o con los demás. Es un terreno neutral donde se encuentran las gentes; donde, sin someterse al fastidio de las visitas de etiqueta y de las presentaciones, se acaba por conocer y entablar amistad; y cuando, como en Granada y Sevilla, se puede añadir el encanto de una fuente o un surtidor, no conozco nada más delicioso.

El patio andaluz es, en resumen, un lugar propicio para el descanso y 
la tertulia, también para la soledad y el ensimismamiento; conforma un ambiente grato y sensitivo, recogido y sugerente, y evita los rigores de la temperatura excesiva. Es, al igual que el trazado de las calles de herencia medieval o mora, el testimonio de una antigua y admirable sabiduría. Hace la casa habitable - no sólo materialmente- y lo hace con una muy sencilla y depurada mezcla de arte y de naturalidad. La atmósfera del patio, cargada de insinuaciones y cadencias, velado ambiente de matices y ritmos peculiares, compendia y simboliza las calidades estéticas y de vida de la ciudad que añora y recrea el viajero romántico.

También interesan aquellos ámbitos del paisaje urbano español donde parecen cobrar vida con más pujanza sus notas características mejores. Plazuelas y jardines, paseos y alamedas, rincones de la ciudad en los que el espíritu romántico encuentra escenarios acordes con su pulso poético y su curiosidad costumbrista. En ellos es frecuente la presencia del arbolado, encarecida siempre y elevada a la categoría de elemento mayor de la personalidad y del atractivo de la ciudad. La preferencia por el bosque se hace ahora preferencia por el verdor del jardín o del claustro, de algunas calles y plazas, de la alameda o del paseo. El árbol sigue siendo uno de los componentes primordiales del paisaje urbano predilecto del viajero romántico. El "Edén de la Alhambra" es, según Quinet (1931: 216, $218,221-2$ ), el "gran alma vegetal que respira en el oasis", ese ambiente de "los jardines, las fuentes, las umbrías, las columnatas, los pabellones de las huries", donde es posible sentir "el efecto de las plantas embriagadoras del Oriente" o "el perfume de los naranjos del patio de Lindaraja".

La ciudad sin árboles es, para el romántico, inhóspita y desagradable; la vegetación anima el paisaje urbano y lo hace acogedor y deseable. Y el viajero se lamenta cuando encuentra a su paso árboles desmedrados o maltratados, jardines sin carácter o decaídos. El juicio de Gautier (1920: I, 163) sobre los jardines madrileños del Buen Retiro es elocuente:

Nosotros, los franceses, que tenemos Versalles y Saint-Cloud, que hemos tenido Marly, somos algo exigentes en esto de residencias reales: el Buen Retiro nos parece a propósito para realizar el sueño de un tendero rico; es un jardín lleno de flores vulgares, pero vistosas; estanquitos adornados con rocalla y bosquecillos vermiculados con juegos de agua del estilo de los escaparates de las tiendas de comestibles; de lagunitas verdosas donde flotan cisnes de madera pintada de blanco y barnizada, y otras maravillas de un gusto dudoso.

El arbolado mejora y realza la calidad del paisaje urbano; su deterioro, su pérdida o su ausencia degradan la ciudad, del mismo modo que su fomento la embellece y la hace más grata. Mérimée (1988: 109, 336) advierte durante su primer viaje, en 1830, que el Museo del Prado "está rodeado de árboles por todos lados, lo que es una agradable rareza en 
este gran desierto árido de Madrid». Más tarde, en 1864, tras la inauguración de la traída de aguas del Lozoya a la capital con el Canal de Isabel II, dice encontrar Madrid "notablemente embellecido", con "árboles y agua por todas partes".

La valoración del arbolado urbano es continua a lo largo de los relatos de los viajeros románticos. Estiman siempre su presencia y son unánimes en la exaltación de aquellos lugares en los que, como en Aranjuez, tal presencia se hace definitiva y esencial. Es Aranjuez, en palabras de Borrow (1921: III, 137-8), unna pequeña ciudad, con un palacio modesto, pero muy lindo, sombreado por árboles enormes", provista de "poderosos cedros y gigantescos álamos y plátanos que forman sus hermosos bosques". En Aranjuez, "el Tajo, que se cruza por un puente colgante, mantiene una frescura en la vegetación —dice Gautier (1920: II, 12)— que causa el asombro de los españoles y permite que los árboles del norte se desarrollen allí con extraordinario vigor". De "los árboles majestuosos de Aranjuez" habla Quinet (1931: 197), al tiempo que resalta "la frescura de los bosquecillos en los jardines clásicos de Felipe V, junto al murmullo de las cascadas del Tajo". Y Aranjuez constituye, para Ford (1980-3: II, 337 , y VIII, 122, 125), un grato "lugar de arroyos, jardines, pájaros canoros y verdor", donde el viajero puede acercarse al "goce del verdadero campo". En este "Oasis" de "verdes prados, jardines, ruiseñores y fuentes", que contrasta con la monocroma y silente desnudez de los alrededores, "parecen haberse reunido - añade- todos los árboles de Castilla".

Los paseos y las alamedas se encuentran entre los ámbitos urbanos que atraen con más fuerza la mirada del viajero romántico. Son lugares en los que al incentivo del arbolado se agrega el gran interés de su significación social y costumbrista. Suelen tener un aire peculiar y un alto valor expresivo: en ellos es posible acercarse a ese conocimiento de ala mentalidad de la gente" que constituye, según Ford (1980-3: I, 13), una de las finalidades de cualquier viajero. "El mejor sitio para estudiar los paseos españoles, y especialmente el de las señoras —escribe el mismo Ford (1980-3: II, 45)—, es la Alameda. Todas las ciudades y pueblos tienen su paseo público, placer barato de todas las clases sociales".

Al Prado de Madrid dedican diversos y a menudo amplios comentarios los viajeros románticos. Es el espejo de la villa y corte, el escenario donde se representa a diario la vida de la capital, con todo su colorido y toda su algarabía, el sitio de "encanto novelesco" donde Quinet (1931: 40, 42) dice haber "reconocido a todas las Vírgenes de Murillo, a la Hija del Aire de Calderón, a la Dorotea de Lope de Vegan. En La maja y el torero - publicada por vez primera en 1847, con el título de Militona-, escribe Gautier (1922: 108): "El Prado, a las siete de la tarde, en estío, es uno de 
los más hermosos paseos del mundo; y no es que sea imposible encontrar en otros sitios umbrías más frescas o lugares más pintorescos; pero en ninguna parte existe una más viva animación ni un más alegre ir y venir de gente". Además, en el Prado madrileño "Sólo se ven mantillas" (Gautier, 1920: I, 133), la emblemática vestimenta que tanto satisface el gusto romántico. “Las mantillas de blancos o negros encajes - sigue el mismo Gautier (1922: 110) — sirven de marco, con sus livianos pliegues, a los más encantadores rostros que nos sea dado ver. La fealdad es un raro accidente». Según Ford (1980-3: VII, 55), el Prado madrileño, "una cosa y una escena puramente españolas, es único; y como no hay nada que se le parezca en toda Europa [...], resulta fascinador para todos los que cruzan los Pirineos".

No son sus árboles, desde luego, los que justifican el interés del Prado madrileño, sino la abigarrada animación de las gentes y costumbres que allí se dejan ver. En otros casos no sucede así. Las narraciones de los viajeros románticos abundan en comentarios acerca de paseos o alamedas en los que, junto a un pulso ciudadano más o menos vivo, cobra una destacada importancia el propio arbolado. Es el caso de la "hermosa alameda" del Esgueva, en Valladolid, o de la no menos apreciable de El Ferrol, "una plantación de un millar de olmos próximamente, casi todos magníficos", a las que se refiere Borrow (1921: II, 59, 239). De los paseos arbolados de Valladolid, y de otros muchos lugares castellanos, habla Ford (1980-3: VI, 147, 168-9): de los "agradables y sombreados" caminos vallisoletanos de las alamedas próximas a los ríos —el Prado de la Magdalena, en el Esgueva; el Espolón nuevo y el Plantío de Moreras, junto al Pisuerga-, y de "la gran Alameda" del "famoso Campo Grande", la "noble Alameda" distribuida "en avenidas y paseos públicos, con jardines florecidos y asientos", donde el viajero puede ponerse al corriente del "rango, la moda, la belleza y los trajes de Valladolid.

Los paseos y las alamedas de las ciudades andaluzas no defraudan la marcada preferencia meridional del viajero romántico. Cruzado el Guadalquivir, Quinet (1931: 261-2) es conducido a Córdoba por «un largo paseo de áloes crecidos en forma de lanzas". El Salón de Granada es, para Gautier (1920: II, 51-2), "uno de los sitios más agradables del mundo": la alameda se compone de unna larga avenida con varias filas de árboles de un verde único en España, terminada en cada extremo por una fuente monumental", y avenidas laterales por donde "corren arroyos de una transparencia cristalina". A ello se suma, entre el Salón y el Genil, "un gran jardín, adornado con surtidores, lleno de flores y arbustos, mirtos, rosales, jazmines". El recuerdo del crepúsculo en la alameda de Granada enciende la prosa siempre colorista de Gautier (1920: II, 53): 
Un espectáculo del que no pueden formar idea los pueblos del norte, es la Alameda de Granada a la puesta del sol. La Sierra Nevada, cuyas dentelladas cumbres señorean la ciudad por aquel lado, adquiere matices incomparables. Todas las escarpas, todas las cimas, heridas de la luz, se tornan color de rosa, pero de un rosa deslumbrador, ideal, fabuloso, nevado de plata, con reflejos de iris y de ópalo, que haría parecer fangosos los tonos más frescos de la paleta; tonos de nácar, transparencias de rubí, venas de ágata y de venturina, capaces de desafiar a todas las joyas mágicas de Las mil y unas noches.

Sevilla no se queda a la zaga de las ciudades andaluzas en cuanto a paseos y alamedas. "La Cristina", cuyo nombre se debe al hecho de haber sido trazado en honor de la mujer de Fernando VII, "es — dice Gautier (1920: II, 199-200) - un paseo magnífico, a orillas del Guadalquivir, con un salón enlosado, circuido de un inmenso banco de mármol blanco con un respaldo de hierro, sombreado de plátanos de Oriente, además de un laberinto, un pabellón chino y toda clase de árboles del Norte - fresnos, cipreses, álamos, sauces-, que son la admiración de los andaluces". Allí es posible ver pasear a "las lindas sevillanas" con sus acompañantes: "tienen —añade - un aire vivo, alegre, ágil, y saltan más que andan". "No hay nada más nacional y pintoresco — señala Ford (1980-3: II, 274)— que este paseo por la tarde, cuando se reúnen allí 'las fuerzas vivas y la gente a la moda', por no decir nada de las clases bajas con sus trajes andaluces de baile de máscaras".

Las imágenes del paisaje urbano contenidas en los relatos de los viajeros románticos extranjeros aciertan a destacar algunos de sus rasgos más significativos y valiosos. Tales imágenes, apoyadas también en los criterios valorativos del paisajismo moderno inaugurado por el romanticismo, tienen la virtud de llamar la atención sobre los componentes cualitativamente más apreciables de la ciudad, y resaltar su importancia en la conformación y en la habitabilidad del conjunto urbano. Los viajeros románticos prestan atención, por ejemplo, a los trazados urbanos tradicionales, y advierten su alto grado de adecuación respecto de las condiciones climáticas existentes, elogian la función de los patios de las casas, elementos primordiales y sabiamente concebidos para mejorar la calidad de la vida urbana en ámbitos cálidos, e insisten en la importancia que adquieren la vegetación, los jardines y los lugares de paseo en la caracterización de las ciudades y en las vivencias y relaciones de sus habitantes. Todo ello se conjuga en las imágenes del paisaje urbano andaluz que ofrecen los relatos de los viajeros románticos. Y tales imágenes constituyen otra de las aportaciones más originales e interesantes del paisajismo moderno que esos viajeros comienzan a practicar. 
Los relatos de los viajeros que recorrieron España durante la primera mitad del siglo XIX ofrecen, en suma, imágenes del paisaje interesantes y valiosas, porque en ellas se expresan con fidelidad los nuevos modos de percibirlo y valorarlo que caracterizan nuestra modernidad. Constituyen así el primer eslabón, el momento inicial, del descubrimiento moderno del paisaje español. La secuencia de la valoración moderna de la Sierra de Guadarrama es, en ese sentido, un ejemplo elocuente y clarificador (Ortega Cantero 1998). Las claves de la nueva valoración romántica del paisaje en las que se apoyan las imágenes de los viajeros muestran, además, notables coincidencias con las que fundamentan la perspectiva paisajística de la geografía moderna, que no hacen sino traducir la significativa proximidad existente entre ambos horizontes.

La nueva manera de entender los paisajes españoles que promovieron los viajeros románticos extranjeros anticipó así en buena medida el modo de acercamiento a esos mismos paisajes que después auspiciaron los enfoques geográficos modernos. Antes de que comenzaran a arraigar en España, en el último tercio del siglo XIX, los puntos de vista de la geografía moderna, los viajeros románticos aportaron un modo de entender el paisaje que adelantaba algunos de los rasgos primordiales de esa perspectiva geográfica. La visión del paisaje español proporcionada por los viajeros románticos extranjeros aporta, en fin, un conjunto de claves cuya presencia, en lo esencial, se mantendrá vigente en la visión paisajística posterior, que incorpora plenamente las sugerencias del horizonte geográfico moderno.

\section{BIBLIOGRAFÍA CITADA}

ALBERICH, J. M. 1981. "En torno a los viajeros ingleses de la época romántica", en Imagen romántica de España. I: 29-36. Madrid: Ministerio de Cultura, 2 t.

- 1987. "Actitudes inglesas ante la Andalucía romántica", en Alberto González Troyano y otros, La imagen de Andalucia en los viajeros románticos y Homenaje a Gerald Brenan: 21-44. Málaga: Diputación Provincial.

Azorín. 1920. Fantasias y devaneos (Política, Literatura, Naturaleza). Madrid: Rafael Caro Raggio.

Borrow, J. 1921. La Biblia en España. O viajes, aventuras y prisiones de un inglés en su intento de difundir las Escrituras por la Peninsula. Traducción de Manuel Azaña. Madrid: Jiménez-Fraud, 3 t.

Dembowski, C. 1931. Dos años en España y Portugal durante la guerra civil, 18381840. Traducción de Domingo Vaca. Madrid: Espasa-Calpe, 2 t.

Dumas, A. 1929. De París a Cádiz (Viaje por España). Traducción de R. Marquina. Madrid: Espasa-Calpe.

FORD, R. 1974. Las cosas de España. Traducción de Enrique de Mesa. Prólogo de Gerald Brenan. Madrid: Turner. 
- 1980-3. I. Manual para viajeros por España y lectores en casa. Observaciones generales. II. Manual para viajeros por Andalucia y lectores en casa. Reino de Sevilla. III. Manual para viajeros por Andalucia y lectores en casa. Reino de Granada. IV. Manual para viajeros por los reinos de Valencia y Murcia y lectores en casa. V. Manual para viajeros por Cataluña y lectores en casa. VI. Manual para viajeros por León y lectores en casa. VII. Manual para viajeros por Castilla y lectores en casa. Parte I: Madrid. VIII. Manual para viajeros por Castilla y lectores en casa. Parte II: Castilla la Vieja. IX. Manual para viajeros por el País Vasco y Navarra y lectores en casa. X. Manual para viajeros por el reino de Aragón y lectores en casa. Traducción de Jesús Pardo, revisada por Bernardo Fernández. Madrid: Turner, $10 \mathrm{t}$.

GaUTIER, T. 1920. Viaje por España. Traducción de Enrique de Mesa. Madrid: Calpe.

- 1922. La maja y el torero. Traducción de Juan de Málaga. Madrid: Jiménez-Fraud, 2. ${ }^{\mathrm{a}}$ ed.

Hugo, V. 1984. Les Pyrénées. Présenté par Danièle Lamarque. París: La Découverte.

Humboldt, A. de. 1874-5. Cosmos. Ensayo de una descripción fisica del mundo. Traducción de Bernardo Giner y José de Fuentes. Madrid: Gaspar y Roig, 4 t.

- 1961. Cuadros de la Naturaleza. Según la edición definitiva, anotada y ampliada por el autor. Traducción de Javier Núñez de Prado. Barcelona: Iberia.

LOCKER, E. H. 1984. Vistas de España. Traducción de José Antonio Zabalbeascoa. Presentación, notas y apéndices de María Dolores Cabra Loredo. Madrid: El Museo Universal.

LóPEz Ontiveros, A. 1988. "El paisaje de Andalucía a través de los viajeros románticos: creación y pervivencia del mito andaluz desde una perspectiva geográfican, en Josefina Gómez Mendoza, Nicolás Ortega Cantero y otros, Viajeros y paisajes: 3165. Madrid: Alianza.

- 1991. La imagen geográfica de Córdoba y su provincia en la literatura viajera de los siglos XVIII y XIX. Córdoba: Monte de Piedad y Caja de Ahorros de Córdoba.

ORTEGa CANTERo, N. 1990. "El paisaje de España en los viajeros románticos". Ería 22: 121-137.

- 1998. "El descubrimiento cultural de la Sierra de Guadarrama", en Madrid y la Sierra de Guadarrama: 81-113. Madrid: Museo Municipal de Madrid.

- 1999. "Romanticismo, paisaje y Geografía. Los relatos de viajes por España en la primera mitad del siglo XIX". Ería 49: 121-128.

- 2000. "Las raíces culturales de la conservación de los paisajes", en Eduardo Martínez de Pisón y Concepción Sanz Herráiz (eds.), Estudios sobre el paisaje: 237-257. Madrid: Universidad Autónoma de Madrid y Fundación Duques de Soria.

Pocock, D. C. D. 1981. "Place and the novelist". Transactions. Institute of British Geographers. New Series 6 (3): 337-347.

QuiNET, E. 1931. Mis vacaciones en España. Traducción de Manuel Núñez de Arenas. Madrid: La Nave.

SAND, G. 1932. Un invierno en Mallorca. Traducción de Pedro Estelrich. Prólogo de Gabriel Alomar. Palma de Mallorca: José Tous.

SENANCOUR. 1930. Obermann. Traducción de Ricardo Baeza. Madrid: Espasa-Calpe. 